\title{
Effects of different sources and levels of dietary gossypol on gossypol residues in plasma and milk of lactating cows
}

\author{
A. P. Wang, ${ }^{\star} \dagger$ J. M. Zhang, ${ }^{1}{ }^{1}$ Y. L. Meng, ${ }^{*}$ L. Q. Deng, ${ }^{\star}$ Y. F. Lv, ${ }^{*} \ddagger$ C. Li, ${ }^{\star}$ and J. Q. Wang ${ }^{\star}$ \\ *State Key Laboratory of Animal Nutrition, Institute of Animal Science, Chinese Academy of Agricultural Sciences, Beijing, 100193 China \\ †College of Animal Science and Technology, Hunan Agriculture University, Changsha, Hunan Province, 410128 China \\ $\ddagger$ College of Animal Science and Technology, South China Agricultural University, Guangzhou, Guangdong Province, 510642 China
}

\section{ABSTRACT}

Free gossypol residues in tissues or milk from feeding whole cottonseed and cottonseed meal were measured for their effect on health of dairy cows and humans. Forty lactating cows were randomly assigned to 5 treatments in a 60-d experiment to investigate the effects of sources and dietary level of gossypol on plasma and milk gossypol concentrations in lactating cows. Five experimental diets had identical net energy for lactation and crude protein content on a dry matter (DM) basis. Soybean meal was the main protein ingredient used in the control diet. Cottonseed meal (CSM) or whole cottonseed (WCS) substituted for part of the soybean meal in the other 4 diets. Gossypol levels in the 5 diets were 0 (control), $91.15 \mathrm{mg} / \mathrm{kg}$ of DM in CSM1, $117.31 \mathrm{mg} /$ $\mathrm{kg}$ of DM in CSM2, $385.43 \mathrm{mg} / \mathrm{kg}$ of DM in WCS1, and $611.13 \mathrm{mg} / \mathrm{kg}$ in WCS2. Yields of $3.5 \%$ fat-corrected milk were significantly higher for cows in the WCS2 group; cows in the CSM1 and WCS1 groups showed no differences but both were numerically higher than the control and CSM2 groups. Milk protein concentration was lower for cows consuming WCS1 compared with the control group. Lactose concentration was lower for cows in the CSM2 group compared with the WCS2 group, but no differences were observed among other diets. Aspartate aminotransferase in serum was significantly higher for the WCS2 group compared with the control and WCS1 groups, but no difference was observed with the CSM1 and CSM2 groups. Concentrations of gossypol in plasma and milk of cows in the WCS1 and WCS2 groups were both higher than those of the other groups. No adverse effects were observed on cows fed diets containing $12.0 \%$ CSM, and no gossypol was found in plasma and milk. When WCS comprised $15 \%$ of the diet DM, yields of $3.5 \%$ fat-corrected milk were increased in cows and gossypol was detected in plasma and milk but not at harmful levels.

Received August 25, 2011.

Accepted May 17, 2012.

${ }^{1}$ Corresponding author: zhjmxms@sina.com.
Key words: cottonseed, cottonseed meal, gossypol, dairy cow

\section{INTRODUCTION}

Whole cottonseed (WCS) and cottonseed meal (CSM) are extensively used as energy and protein sources in dairy cattle diets. However, both contain gossypol, a polyphenolic binaphthyl dialdehyde that can produce toxic effects in animals. Gossypol exists in free and bound forms. Free gossypol (FG) is toxic to animals, whereas the bound form is considered nontoxic because it cannot be absorbed in the digestive tract. Some researchers have found that bound gossypol may be released as FG during the digestion process, which can be absorbed by the digestive tract (Blackwelder et al., 1998; Noftsger et al., 2000; Mena et al., 2001). Absorbed gossypol either is retained in organs such as the kidney and in muscle, or it is excreted via feces, urine, or milk (Lin et al., 1992; Gamboa et al., 2001a,b; Wan et al., 2003). If the contaminated tissues or milk are consumed by humans, they could have detrimental effects. Thus, it is necessary to pay close attention to gossypol concentrations in animal products, but as yet, little information has been made available on gossypol residues in milk. Only 2 studies have reported milk gossypol concentrations of dairy cows, but used only limited numbers of animals (Zhong, 2007) or inappropriate detection methods (Wan et al., 2003). Objectives of this study were to feed varying amounts of gossypol from WCS or CSM over a long period of time and determine effects on plasma and milk gossypol concentrations in lactating dairy cows.

\section{MATERIALS AND METHODS}

\section{Experimental Design}

Design and Treatments. The experimental design was a randomized complete block. Cows were blocked according to parity and milk yield or age at calving, and randomly assigned to 1 of 5 diets. Forty early lacta- 
tion Holstein cows $(86 \pm 25$ DIM) were assigned to 1 of 5 treatment diets ( 8 cows per diet) on the basis of parity, DIM, daily milk yield, and age at calving. The study period lasted $70 \mathrm{~d}$. During a $10-\mathrm{d}$ pretreatment period, all cows were fed a gossypol-free diet, which was also the control diet during the treatment period (control; Table 1). Experimental diets were fed as TMR and varied in their amounts of forage and concentrate to accommodate different amounts of CSM and WCS. Diets were formulated to be isonitrogenous and isoenergetic, and met the requirements of feeding standards of dairy cows [China NongYe HangYe Biaozhun/ Tuijian-34 (China NY/t34, 2004)]. Detailed descriptions of dietary ingredients and nutrient composition are presented in Table 1.Cows were assigned to 1 of 5 treatment groups: no gossypol (control group), 91.15 $\mathrm{mg}$ of $\mathrm{FG} / \mathrm{kg}$ from CSM (CSM1 group), $117.31 \mathrm{mg}$ of FG/kg from CSM (CSM2 group), $385.43 \mathrm{mg}$ of FG/ $\mathrm{kg}$ from WCS (WCS1 group), or $611.13 \mathrm{mg}$ of $\mathrm{FG} / \mathrm{kg}$ from WCS (WCS2 group).
Animals and Housing. Cows were housed in open pens equipped with a neck rail. When feeding, all cows were tied alone to enable taking measurements of daily feed intakes from individual cows. All pens were identical in design, size, and location. Diets were fed twice daily at 0500 to 0830 and 1700 to $2030 \mathrm{~h}$. Cows were milked twice daily at 0500 and $1700 \mathrm{~h}$. Water was available ad libitum.

\section{Measurements and Data}

Feed Intake and Feed. Whole cottonseed and CSM were both from Yongqing, Hebei Province, China. Individual feed intakes were recorded daily during the trial period, and the TMR composition is presented in Table 1.

Milk Yield and Composition. Individual milk samples were collected on d $0,15,30,45$, and 60 of the experimental period, milk yields recorded, and milk analyzed for fat, protein, lactose, and SNF by infrared

Table 1. Ingredient and nutrient composition of diets

\begin{tabular}{|c|c|c|c|c|c|}
\hline \multirow[b]{2}{*}{ Composition } & \multicolumn{5}{|c|}{ Treatment $^{1}$} \\
\hline & Control & CSM1 & CSM2 & WCS1 & WCS2 \\
\hline \multicolumn{6}{|c|}{ Ingredient, $\mathrm{g} / 100 \mathrm{~g}$ of $\mathrm{DM}$} \\
\hline Alfalfa hay & 14.2 & 15.0 & 14.8 & 14.5 & 14.2 \\
\hline Corn straw & 25.8 & 25.4 & 25.2 & 26.3 & 26.7 \\
\hline Corn & 30.2 & 32.7 & 32.7 & 24.2 & 21.7 \\
\hline Wheat bran & 6.4 & 1.4 & 1.4 & 6.6 & 6.7 \\
\hline Soybean meal & 19.8 & 12.3 & 10.3 & 14.8 & 12.1 \\
\hline Cottonseed meal ${ }^{2}$ & 0.0 & 9.6 & 12.0 & 0.0 & 0.0 \\
\hline Whole cottonseed ${ }^{3}$ & 0.0 & 0.0 & 0.0 & 10.0 & 15.0 \\
\hline $5 \%$ Premix $^{4}$ & 3.0 & 3.0 & 3.0 & 3.0 & 3.0 \\
\hline Salt & 0.6 & 0.6 & 0.6 & 0.6 & 0.6 \\
\hline \multicolumn{6}{|l|}{ Chemical, $\mathrm{g} / 100 \mathrm{~g}$ of $\mathrm{DM}$} \\
\hline DM & 90.34 & 90.68 & 90.71 & 90.30 & 90.27 \\
\hline $\mathrm{NE}_{\mathrm{L}},{ }^{5} \mathrm{Mcal} / \mathrm{kg}$ of $\mathrm{DM}$ & 1.54 & 1.54 & 1.54 & 1.54 & 1.54 \\
\hline NDF & 39.20 & 38.92 & 39.06 & 43.39 & 45.60 \\
\hline $\mathrm{ADF}$ & 23.16 & 23.92 & 24.09 & 26.90 & 28.84 \\
\hline Fat & 4.21 & 3.91 & 3.88 & 5.51 & 6.47 \\
\hline $\mathrm{CP}$ & 15.70 & 15.70 & 15.70 & 15.70 & 15.70 \\
\hline Calcium & 0.73 & 0.71 & 0.70 & 0.73 & 0.74 \\
\hline Phosphorus & 0.81 & 0.85 & 0.86 & 0.84 & 0.86 \\
\hline $\mathrm{TG}, \mathrm{mg} / \mathrm{kg}$ of $\mathrm{DM}$ & 0.00 & 651.97 & 839.08 & 816.66 & $1,294.88$ \\
\hline $\mathrm{FG}, \mathrm{mg} / \mathrm{kg}$ of $\mathrm{DM}$ & 0.00 & 91.15 & 117.31 & 385.43 & 611.13 \\
\hline
\end{tabular}

${ }^{1}$ Cows were assigned to 1 of 5 treatment groups: no gossypol (control group), $91.15 \mathrm{mg}$ of free gossypol (FG)/ $\mathrm{kg}$ free from cottonseed meal (CSM, CSM1 group), 117.31 mg of FG/kg from CSM (CSM2 group), 385.43 $\mathrm{mg}$ of FG/kg from whole cottonseed (WCS, WCS1 group), or $611.13 \mathrm{mg}$ of FG/kg FG WCS (WCS2 group).

${ }^{2}$ Consisted of DM (90.98\%), CP (39.08\%), ether extract (EE; 0.29\%), ADF (22.76\%), NDF (36.00\%), FG $(902.27 \mathrm{mg} / \mathrm{kg}$ ), and total gossypol (TG; $6,453.66 \mathrm{mg} / \mathrm{kg})$.

${ }^{3}$ Consisted of DM (90.38\%), CP (21.22\%), EE (18.39\%), ADF $(22.76 \%)$, NDF (36.00\%), FG (3,666.89 mg/kg), and TG $(7,769.52 \mathrm{mg} / \mathrm{kg})$.

${ }^{4}$ Premix composition: vitamin A, 12,240 IU/kg; vitamin $\mathrm{D}_{3}, 3,670 \mathrm{IU} / \mathrm{kg}$; vitamin E, 67,600 IU/kg; Fe, 33.65 $\mathrm{mg} / \mathrm{kg} ; \mathrm{Cu}, 25.1 \mathrm{mg} / \mathrm{kg} ; \mathrm{Mn}, 30.59 \mathrm{mg} / \mathrm{kg} ; \mathrm{Zn}, 107.6 \mathrm{mg} / \mathrm{kg} ; \mathrm{I}, 1.10 \mathrm{mg} / \mathrm{kg} ; \mathrm{Se}, 0.67 \mathrm{mg} / \mathrm{kg} ; \mathrm{Co}, 0.54 \mathrm{mg} / \mathrm{kg}$; Ca, $3.06-4.59 \mathrm{mg} / \mathrm{kg} ; \mathrm{P}, 0.92-1.99 \mathrm{mg} / \mathrm{kg} ;$ and salt, $4.59-7.34 \mathrm{mg} / \mathrm{kg}$.

${ }^{5}$ Calculated value (based on Ministry of Agriculture of the People's Republic of China, 2004). 
Table 2. Effects of dietary supplementation with cottonseed meal (CSM) or whole cottonseed (WCS) on lactation performance in lactating cows

\begin{tabular}{|c|c|c|c|c|c|c|}
\hline \multirow[b]{2}{*}{ Item } & \multicolumn{5}{|c|}{ Treatment $^{1}$} & \multirow[b]{2}{*}{$\mathrm{SEM}^{2}$} \\
\hline & Control & CSM1 & CSM2 & WCS1 & WCS2 & \\
\hline DMI, $\mathrm{kg} / \mathrm{d}$ & 22.1 & 21.8 & 22.3 & 21.6 & 21.3 & 0.30 \\
\hline $\mathrm{FGI}^{3}{ }^{3} \mathrm{~g} / \mathrm{d}$ & $0.00^{\mathrm{e}}$ & $1.98^{\mathrm{d}}$ & $2.62^{\mathrm{c}}$ & $8.32^{\mathrm{b}}$ & $13.02^{\mathrm{a}}$ & 0.07 \\
\hline $3.5 \%$ FCM, $\mathrm{kg} / \mathrm{d}$ & $14.1^{\mathrm{c}}$ & $16.0^{\mathrm{b}}$ & $14.9^{\mathrm{c}}$ & $16.1^{\mathrm{b}}$ & $16.9^{\mathrm{a}}$ & 0.62 \\
\hline Milk protein, $\%$ & $3.58^{\mathrm{ab}}$ & $3.68^{\mathrm{a}}$ & $3.55^{\mathrm{ab}}$ & $3.34^{\mathrm{c}}$ & $3.41^{\mathrm{bc}}$ & 0.04 \\
\hline Milk fat, $\%$ & 3.31 & 3.54 & 3.51 & 3.21 & 3.36 & 0.08 \\
\hline Lactose, \% & $4.43^{\mathrm{ab}}$ & $4.47^{\mathrm{ab}}$ & $4.31^{\mathrm{b}}$ & $4.43^{\mathrm{ab}}$ & $4.58^{\mathrm{a}}$ & 0.04 \\
\hline SNF, $\%$ & 8.84 & 9.00 & 8.67 & 8.64 & 8.81 & 0.05 \\
\hline \multicolumn{7}{|c|}{${ }^{\mathrm{a} e}$ Values with different superscripts in the same row indicate significant statistical differences $(P<0.05)$. } \\
\hline \multicolumn{7}{|c|}{$\begin{array}{l}{ }^{1} \text { Cows were assigned to } 1 \text { of } 5 \text { treatment groups: no gossypol (control group), } 91.15 \mathrm{mg} \text { of free gossypol (FG) } \\
\mathrm{kg} \text { from CSM (CSM1 group), } 117.31 \mathrm{mg} \text { of FG/kg from CSM (CSM2 group), } 385.43 \mathrm{mg} \text { of FG/kg from WC } \\
\text { (WCS1 group), or } 611.13 \mathrm{mg} \text { of FG/kg from WCS (WCS2 group). The original date of each replicate is a } \\
\text { average of dates collecting at } 15,30,45 \text {, and } 60 \mathrm{~d} \text { before analysis. } \\
{ }^{2} \text { Standard error of least squares means. }\end{array}$} \\
\hline
\end{tabular}

analysis (Foss MilkoScan; Foss Food Technology Corp., Eden Prairie, MN).

Plasma and Serum Parameters. Blood samples $(10 \mathrm{~mL})$ were collected from 15 cows $(3$ cows per treatment) on d 0,30 , and 60 of the experimental period by coccygeal artery puncture using tubes containing anticoagulant (sodium heparin; Greiner Bio-One GmbH, Stonehouse, UK) or no anticoagulant agent for separation of plasma and serum, respectively. Blood samples were immediately placed on ice and transported to the laboratory within $3 \mathrm{~h}$ of collection. After blood coagulated, blood tubes were centrifuged at $3,000 \times g$ for 10 min in a refrigerated centrifuge at about $10^{\circ} \mathrm{C}$ for plasma or serum separation. Plasma was frozen at $-20^{\circ} \mathrm{C}$ and later analyzed for urea $\mathrm{N}$ and gossypol. Serum samples were also frozen at $-20^{\circ} \mathrm{C}$ and later analyzed for their concentrations of aspartate aminotransferase (AST) and alanine aminotransferase (ALT).

Free Gossypol and Total Gossypol. The FG and total gossypol in CSM and WCS (Wu and Xu, 2009), plasma samples (Kim and Calhoun, 1995), and milk samples (Zhong, 2007) were determined by HPLC.

Statistical Analysis. The data were analyzed as a completely randomized design with repeated measures using the MIXED procedures of SAS (SAS Institute Inc., Cary, NC). Fixed effects included treatment, day, and treatment $x$ day interaction. The variance for cow nested within treatment was used as the random error term to test the main effect of treatment. The day of collection was a repeated measure (compound symmetry covariance structure). Data are presented as covariate adjusted least squares means. The significance level was declared at $P<0.05$.

\section{RESULTS}

\section{Lactation Performance}

Dry matter intake was not affected by gossypol intake from CSM or WCS, and averaged $21.74 \mathrm{~kg} / \mathrm{d}$ (Table 2 ). Compared with the control group, treatments had greater $3.5 \% \mathrm{FCM}(P<0.05)$, except for the CSM2 group $(P>0.05)$. Milk protein concentration was lower for cows consuming WCS1 compared with the control group $(P<0.05)$. Lactose concentrations were lower for cows in the CSM2 group compared with the WCS2 group $(P<0.05)$, but no differences were observed among other diets $(P>0.05)$.

\section{Plasma and Serum Parameters}

No differences (Table 3) were observed in ALT and urea $\mathrm{N}$ among control and treatment groups $(P>0.05)$. Cows of the WCS2 group had higher AST concentrations than the control and WCS1 groups $(P<0.05)$, but no difference was observed between the CSM1 and CSM2 groups $(P>0.05)$.

\section{Plasma Gossypol and Milk Gossypol}

Gossypol was not transferred to plasma and milk in cows fed CSM (Figure 1). However, plasma and milk gossypol concentrations in cows consuming WCS were both greater than other treatment groups $(P<0.05)$. The concentration of plasma gossypol in WCS2 group at $60 \mathrm{~d}$ was greater than that in the WCS1 group ( $P$ $<0.05)$. And the concentration of milk gossypol in the 
Table 3. Concentrations of alanine aminotransferase (ALT) and aspartate aminotransferase (AST) in serum and urea $\mathrm{N}$ in plasma of lactating dairy cows fed varying amounts of gossypol from cottonseed meal (CSM) and whole cottonseed (WCS)

\begin{tabular}{lcccccc}
\hline & \multicolumn{5}{c}{ Treatment $^{1}$} \\
\cline { 2 - 5 } Item & Control & CSM1 & CSM2 & WCS1 & WCS2 & \multirow{2}{*}{ SEM $^{2}$} \\
\hline ALT, U/L & 35.8 & 32.6 & 33.4 & 33.6 & 36.0 & 1.77 \\
AST, U/L & $67.6^{\text {bc }}$ & $74.8^{\text {ab }}$ & $69.4^{\text {abc }}$ & $65.4^{\text {c }}$ & $77.8^{\text {a }}$ & 2.05 \\
Urea N, mmol/L & 4.81 & 4.57 & 4.66 & 4.20 & 4.77 & 0.11 \\
\hline
\end{tabular}

${ }^{a-c}$ Values with different superscripts in the same row indicate significant statistical differences $(P<0.05)$.

${ }^{1}$ Cows were assigned to 1 of 5 treatment groups: no gossypol (control group), $91.15 \mathrm{mg}$ of free gossypol (FG)/ $\mathrm{kg}$ from CSM (CSM1 group), $117.31 \mathrm{mg}$ of FG/ $\mathrm{kg}$ from CSM (CSM2 group), $385.43 \mathrm{mg}$ of FG $/ \mathrm{kg}$ from WCS (WCS1 group), or $611.13 \mathrm{mg}$ of FG/kg from WCS (WCS2 group). The original date of each replicate is an average of dates collecting at 30 and $60 \mathrm{~d}$ before analysis.

${ }^{2}$ Standard error of least squares means.

WCS2 group at 30 and $60 \mathrm{~d}$ was also higher than that in the WCS1 group $(P<0.05)$.

\section{DISCUSSION}

Cottonseed byproduct did not affect DMI when CSM or WCS replaced wheat bran and soybean meal in diets for lactating dairy cows containing $12 \%$ of DM as CSM or $15 \%$ of DM as WCS, and the total intake of FG was up to $13.02 \mathrm{~g} / \mathrm{d}$. Prieto et al. (2003) indicated that substitution of cracked Pima cottonseed with whole linted Upland cottonseed had no effect on DMI of primiparous and multiparous cows receiving $12 \%$ of DM. Thus, available data indicated no effect on DMI when CSM or WCS partially replaced other ingredients in diets of dairy cows.

Yield of 3.5\% FCM may be improved by adding WCS or CSM. But WCS was more effective $(P<0.05)$ than other diets in increasing 3.5\% FCM. This was probably because of higher fat concentration (Table 1) in those diets containing WCS, resulting in increased energy content. Others have observed similar responses (Coppock et al., 1987; Mena et al., 2001). Milk protein concentrations were lower for diets with WCS, which is supported by previous work by Smith et al. (1981) and Mena et al. (2001). Although responsible for greater milk production, the higher fat content in diets with $15 \%$ WCS probably caused the depression in milk protein content. Preferential accumulation of gossypol in the liver has been studied in several livestock animal species, such as sheep (Morgan, 1990), pigs (Sharma et al., 1966), and broiler chickens (Gamboa et al., 2001a,b). To confirm that hepatic function was not affected by dietary gossypol, we evaluated activity of urea N, AST, and ALT in serum as associated with hepatic cell viability. These indexes occur in most cells, but are usually increased in serum when hepatocyte cells have suffered cellular damage (Barraza et al., 1991; Kreutzer et al.,
2008). Concentrations of ALT in serum and urea $\mathrm{N}$ in plasma were both unaffected by diets, which agree with the results of other studies (Higginbotham et al., 2004; Mena et al., 2004; McCaughey et al., 2005). Compared with control and CSM2 groups, concentrations of AST in WCS2 fed cows were higher, which was similar to findings in other studies (Mena et al., 2004). Although
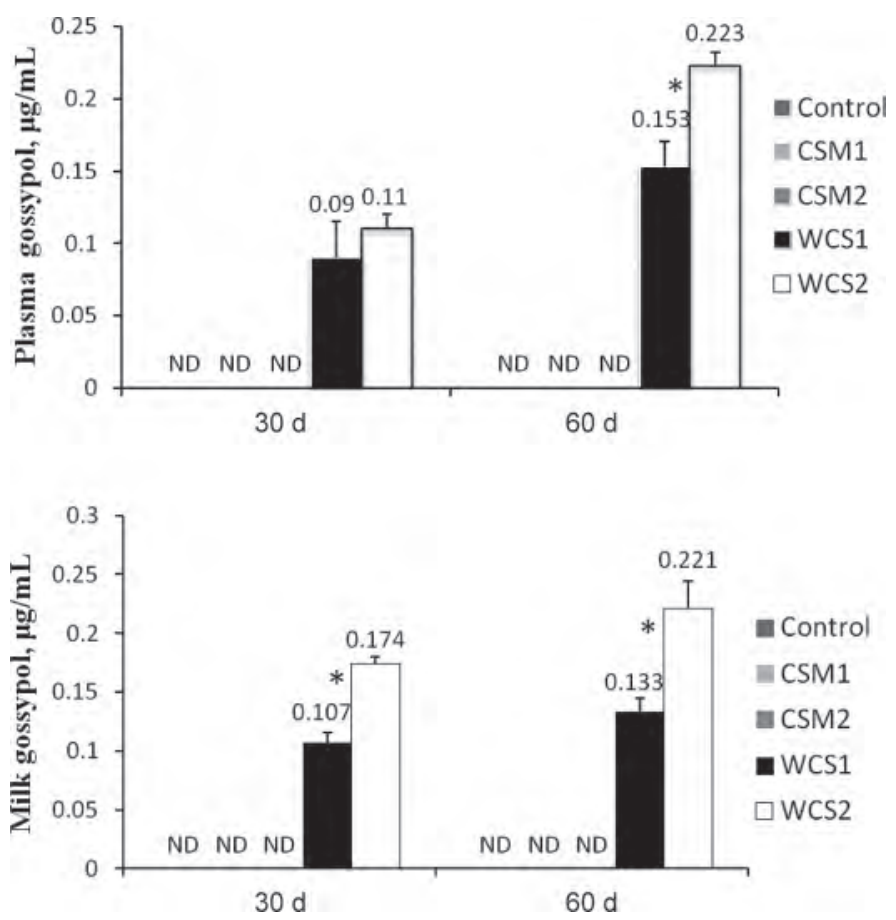

Figure 1. Plasma and milk gossypol concentrations of lactating dairy cows fed varying levels of gossypol from cottonseed meal (CSM) and whole cottonseed (WCS): no gossypol (control), $91.15 \mathrm{mg}$ of free gossypol (FG)/kg from CSM (CSM1), $117.31 \mathrm{mg}$ of $\mathrm{FG} / \mathrm{kg}$ from CSM (CSM2), $385.43 \mathrm{mg}$ of $\mathrm{FG} / \mathrm{kg}$ from WCS (WCS1), or $611.13 \mathrm{mg}$ of $\mathrm{FG} / \mathrm{kg}$ from WCS (WCS2). The concentrations of plasma and milk gossypol were detected only in WCS1 and WCS2 groups. ND = not detected (control, CSM1, and CSM2). Results represent mean \pm standard error. ${ }^{*} P<0.05$, WCS1 versus WCS2. 
$15 \%$ WCS increased the AST concentration in serum, values observed were within the normal range for cows (43-127 IU/L; Kreutzer et al., 2008).

No gossypol was transferred to blood in cows consuming less than $3 \mathrm{~g}$ of FG/d (CSM1 and CSM2), but cows receiving more than $8 \mathrm{~g}$ of $\mathrm{FG} / \mathrm{d}$ (WCS1 and WCS2) had higher plasma gossypol concentrations. Plasma concentration is a marker for gossypol bioavailability and may be used to assess the amount of cottonseed products that can be used safely (Blackwelder et al., 1998; Santos et al., 2002, 2003). Noftsger et al., (2000) found that no signs of clinical gossypol toxicity were observed when cows consumed 21.6 and $30.9 \mathrm{~g}$ of FG/d from WCS. Santos et al., (2003) observed that lactating cows consuming $22.8 \mathrm{~g}$ of FG/d from WCS for a period of $170 \mathrm{~d}$ had marked increases in plasma gossypol, but this did not affect health, culling, or mortality of cows. Visible signs of gossypol toxicity including dyspnea, anorexia, decreased milk production, weakness, and sudden death were not observed in any of the cows in a study by Mena et al. (2004). Therefore, based on data and findings from other researchers, Millard (2002) suggested that $5 \mu \mathrm{g} / \mathrm{mL}$ be considered the safe upper limit for plasma gossypol in dairy cattle fed cotton feed products for extended periods.

Gossypol is transferred to edible parts, muscle and offal of ruminants and poultry, and is probably transferred to cow's milk, as it is transferred to milk in rats (Lin et al., 1992). However, very little quantitative information exists on the transfer of gossypol in feed to milk of cows. Only few studies reported milk gossypol concentrations of lactating dairy cows, but used either limited numbers of animals (Zhong, 2007) or colorimetry to determine gossypol concentration, which is considered an unreliable technique (Wan et al., 2003). Extracted gossypol is determined spectrophotometrically (at 440 $\mathrm{nm}$ ) as adduct (Schiff base) with aniline (i.e., dianilinogossypol; European Commission, 1972). Specificity of this method is questionable, as compounds other than gossypol can contribute to formation of UV adsorption at $440 \mathrm{~nm}$. However, some gossypol-like compounds (e.g., gossypol methyl ethers of presumably similar toxicity as gossypol) will be codetermined with gossypol in spectrophotometric methods. High-performance liquid chromatography determination of gossypol is preferred, as it offers a higher degree of specificity (Chamkasem, 1988; Hron et al., 1990; Jaroszewski et al., 1992).

We used HPLC to detect gossypol in milk and found no gossypol in milk of cows fed cottonseed meal (CSM1 and CSM2), whereas milk gossypol levels in cows receiving $8 \mathrm{~g}$ of $\mathrm{FG} / \mathrm{d}$ originating from cottonseed were 0.133 and $0.221 \mu \mathrm{g} / \mathrm{mL}$ for WCS groups at $60 \mathrm{~d}$. Wan et al., (2003) fed 18 lactating Holstein cows a diet with $2.8 \%$ WCS and $16.5 \%$ CSM, which provided $5.1 \mathrm{~g}$ of total gossypol/d, for $104 \mathrm{~d}$, using colorimetry to determine the gossypol in milk, and found no gossypol. Zhong (2007) fed 8 Holstein cows with 0, 5, 10, and $15 \%$ WCS, which provided $0,6.3,12.93$, and $20.34 \mathrm{~g}$ of $\mathrm{FG} / \mathrm{d}$, respectively, for $120 \mathrm{~d}$, in a replicated $4 \times$ 4 Latin square design. Zhong (2007) used HPLC and found that residual levels of gossypol in milk were 0 , $0.2,0.24$, and $0.32 \mathrm{mg} / \mathrm{kg}$, respectively. Maximum residue limits of FG in food determined by the Food and Agriculture Organization (FAO) and US Food and Drug Administration (FDA) were 0.06 and $0.045 \%$, respectively. According to these data, we found that milk gossypol concentration was lower than the maximum residue limits of FG.

\section{CONCLUSIONS}

When cows were fed up to 117.31 or $611.13 \mathrm{mg}$ of dietary $\mathrm{FG} / \mathrm{kg}$ from cottonseed meal or whole cottonseed, respectively, plasma and milk free gossypol concentrations were below the safe upper limit for dairy cows.

\section{REFERENCES}

Barraza, M. L., C. E. Coppock, K. N. Brooks, D. L. Wilks, R. G. Saunders, and G. J. Latimer. 1991. Iron sulfate and feed pelleting to detoxify free gossypol in cottonseed diets for dairy cattle. J. Dairy Sci. 74:3457-3467.

Blackwelder, J. T., B. A. Hopkins, D. E. Diaz, L. W. Whitlow, and C. Brownie. 1998. Milk production and plasma gossypol of cows fed cottonseed and oilseed meals with or without rumen-undegradable protein. J. Dairy Sci. 81:2934-2941.

Chamkasem, N. 1988. Gossypol analysis in cottonseed oil by HPLC J. Am. Oil Chem. Soc. 65:1601-1604.

China NY/t34 (China NongYe HangYe Biaozhun/Tuijian-34). 2004. Feeding standard of dairy cattle. China NongYe HangYe Biaozhun/Tuijian-34. China Agricultural Publisher, Beijing, China.

Coppock, C. E., J. K. Lanham, and J. L. Horner. 1987. A review of the nutritive value and utilization of whole cottonseed, cottonseed meal and associated by-products by dairy cattle. Anim. Feed Sci. Technol. 18:89-129.

European Commission. 1972. Third Commission Directive 72/199/ EEC of 27 April 1972 establishing Community methods of analysis for the official control of feedingstuffs $(72 / 199 /$ EEC) 5 . Determination of free gossypol. European Commission, Brussels, Belgium.

Gamboa, D. A., M. C. Calhoun, S. W. Kuhlmann, A. U. Haq, and C. A. Bailey. 2001a. Tissue distribution of gossypol enantiomers in broilers fed various cottonseed meals. Poult. Sci. 80:920-925.

Gamboa, D. A., M. C. Calhoun, S. W. Kuhlmann, A. U. Haq, and C. A. Bailey. 2001b. Use of expander cottonseed meal in broiler diets formulated on a digestible amino acid basis. Poult. Sci. 80:789794.

Higginbotham, G. E., J. E. P. Santos, and E. J. Depeters. 2004. Effects of pelleting whole cottonseed on plasma gossypol, rumen metabolites, and performance of lactating dairy cows. Prof. Anim. Sci. 20:413-421.

Hron, R. J., M. S. Kuk, and G. Abraham. 1990. Determination of free and total gossypol by high performance liquid chromatography. J. Am. Oil Chem. Soc. 67:182-187.

Jaroszewski, J. W., T. Strøm-Hansen, S. H. Hansen, O. Thastrup, and H. Kofod. 1992. On the botanical distribution of chiral forms of gossypol. Planta Med. 58:454-458. 
Kim, H. L., and M. C. Calhoun. 1995. Determination of gossypol in plasma and tissues of animals. Inform 6:486. (Abstr.)

Kreutzer, K. V., J. R. Turk, and S. W. Casteel. 2008. Clinical Biochemistry in Toxicology. Pages 821-837 in Clinical Biochemistry of Domestic Animals. 6th ed. J. J. Kaneko, J. W. Harvey, and M. L. Bruss, ed. Academic Press, Burlington, MA.

Lin, Y. C., Y. F. Hu, C. J. Chang, P. P. Moh, and S. K. Kulp. 1992. Transfer of $3 \mathrm{H}$-gossypol to neonatal rats via milk of nursing dams. Life Sci. 51:1657-1665.

McCaughey, K. M., E. J. DePeters, P. H. Robinson, J. E. P. Santos, J. W. Pareas, and S. J. Taylor. 2005. Impact of feeding whole Upland cottonseed, with or without cracked Pima cottonseed with increasing addition of iron sulfate, on productivity and plasma gossypol of lactating dairy cattle. Anim. Feed Sci. Technol. 122:241-256.

Mena, H., J. E. P. Santos, J. T. Huber, J. M. Simas, M. Tarazon, and M. C. Calhoun. 2001. The effects of feeding varying amounts of gossypol from whole cottonseed and cottonseed meal in lactating dairy cows. J. Dairy Sci. 84:2231-2239.

Mena, H., J. E. P. Santos, J. T. Huber, M. Tarazon, and M. C. Calhoun. 2004. The effects of varying gossypol intake from whole cottonseed and cottonseed meal on lactation and blood parameters in lactating dairy cows. J. Dairy Sci. 87:2506-2518.

Millard, C. C. 2002. Cottonseed meal and whole cottonseed: Optimizing their use in dairy cattle rations. TX Agric. Exp. Station, Texas A\&M Univ. System, San Angelo.

Morgan, S. E. 1990. Gossypol residues in organ meats vs thresholds of toxicity. Vet. Hum. Toxicol. 32:76-79.

Noftsger, S. M., B. A. Hopkins, D. E. Diaz, and L. W. Whitlow. 2000. Effect of whole and expanded-expelled cottonseed on milk yield and blood gossypol. J. Dairy Sci. 83:2539-2547.
Prieto, J. G., E. J. DePeters, P. H. Robinson, J. E. P. Santos, J. W Pareas, and S. J. Taylor. 2003. Increasing dietary levels of cracked Pima cottonseed increase plasma gossypol but do not influence productive performance of lactating Holstein Cows. J. Dairy Sci. $86: 254-267$.

Santos, J. E., M. Villaseňor, E. J. Depeters, P. H. Robinson, and B. C. J. Baldwin Jr. 2002. Type of cottonseed and level of gossypol in diets of lactating dairy cows: Effects on lactation performance and plasma gossypol. J. Dairy Sci. 85:1491-1501.

Santos, J. E., M. Villasenor, E. J. Depeters, P. H. Robinson, B. C. J. Baldwin, and C. A. Holmberg. 2003. Type of cottonseed and level of gossypol in diets of lactating dairy cows: Plasma gossypol, health, and reproductive performance. J. Dairy Sci. 86:892-905.

Sharma, M. P., F. H. Smith, and A. J. Clawson. 1966. Effects of levels of protein and gossypol, and length of feeding period on the accumulation of gossypol in tissues of swine. J. Nutr. 88:434-438.

Smith, N. E., L. S. Collar, D. L. Bath, W. L. Dunkley, and A. A. Franke. 1981. Digestibility and effects of whole cottonseed fed to lactating cows. J. Dairy Sci. 64:2209-2215.

Wan, F. C., N. X. Yu, N. K. Wu, and E. L. Song. 2003. Effect of cotton hydroxybenzene on milkability of dairy cow. Chinese J. Anim. Sci. 39:22-23.

Wu, W. W., and G. R. Xu. 2009. Determination of free gossypol in cottonseed cake feed by HPLC. J. Agric. Univ. of Hebei. 32:105-107.

Zhong, R. Z. 2007. Performance and composition of milk fat of Holstein cows fed whole cottonseed during early lactation. MS Thesis. Hebei Agric. Univ., Shijiazhuang, China. 